\section{Acknowledgments.}

Financial support. A received funding from Thammasat University Hospital for COVID-19 research.

Conflicts of interest. All authors report no conflicts of interest relevant to this article.

\section{References}

1. Lobo JL, Del Ser J, Bifet A, Kasabov N. Spiking neural networks and online learning: an overview and perspectives. Neural Networks 2020;121:88-100.

2. Li, G, Li W, He X, Cao Y. Asymptomatic and presymptomatic infectors: hidden sources of coronavirus disease 2019 (COVID-19). Clin Infect Dis 2020;71:2018.
3. Zimmerman KO, Akinboyo IC, Brookhart MA, et al. Incidence and secondary transmission of SARS-CoV-2 infections in schools. Pediatrics 2021. doi: 10.1542/peds.2020-048090.

4. Apisarnthanarak A, Apisarnthanarak P, Siripraparat C, Saengaram P, Leeprechanon N, Weber DJ. Impact of anxiety and fear for COVID-19 toward infection control practices among Thai healthcare workers. Infect Control Hosp Epidemiol 2020;41:1093-1094.

5. Apisarnthanarak A, Siripraparat C, Apisarnthanarak P, et al. Patients' anxiety, fear, and panic related to coronavirus disease 2019 (COVID-19) and confidence in hospital infection control policy in outpatient departments: a survey from four Thai hospitals. Infect Control Hosp Epidemiol 2020. doi: $10.1017 /$ ice.2020.1240.

6. Cullen W, Gulati G, Kelly BD. Mental health in the COVID-19 pandemic. QJM 2020;113:311-312.

\title{
Coronavirus disease 2019 (COVID-19) transmission events in school staff in a Brazilian prospective cohort
}

\author{
Rodrigo Pires dos Santos PhD, Stephani Amanda Lukasewicz Ferreira Msc, Otávio Luiz da Fontoura Carvalho PharmaD, \\ Camila Hubner Dalmora MD, Robson Dornelles Ruiz IT, Arateus Menezes IT and Tiago Andres Vaz MSc
}

Qualis, Porto Alegre, Rio Grande do Sul, Brazil

To the Editor-Since the emergence of the severe acute respiratory coronavirus virus 2 (SARS-CoV-2) and global pandemic declaration, the recommendation to embrace nonpharmaceutical public health measures has been established, including nonessential business and school closures. Despite some uncertainty, studies have temporally associated school closure with decreased coronavirus disease 2019 (COVID-19) incidence and mortality. ${ }^{1,2}$ However, recent research has revealed lower attack rates for children, and they might be less susceptible to SARS-CoV-2 infection. ${ }^{3,4}$ The balance between the risks of SARS-CoV-2 infection to children and the adverse events of isolation and social distance to their educational and socioemotional skill development is still a matter of debate. ${ }^{5}$ Transmission between staff is more common than transmission between students and staff or among students. ${ }^{6}$

\section{Methods}

We studied a cohort of school staff from 3 institutions in Rio Grande do Sul, Brazil's southernmost state, from October 1, 2020, to December 31, 2020. In-person learning was closed from March to September 2020. In total, 768 students attended onsite classes during the study period. The 3 schools followed a hybrid model in which students attended classes on alternate days. According to the state law, each classroom could support $50 \%$ of students, with $1.5 \mathrm{~m}$ between students.

The schools' preparedness included the availability of alcoholbased hand rub, disinfectants for environment cleaning, and staff education. Classrooms were organized to maintain a distance of at

\footnotetext{
Author for correspondence: Rodrigo Pires dos Santos, E-mail: rodrigo@portalqualis. com.br

Cite this article: dos Santos RP, et al. (2022). Coronavirus disease 2019 (COVID-19) transmission events in school staff in a Brazilian prospective cohort. Infection Control \& Hospital Epidemiology, 43: 1309-1310, https://doi.org/10.1017/ice.2021.255
}

least $1.5 \mathrm{~m}$ between students. Toys or shared materials were accessed for cleaning, and unnecessary materials were taken out of classrooms. Natural ventilation with doors and windows open was simulated at all times. The cafeteria and dining halls were closed. Students and staff had to wear masks while in school, except those aged $<6$ years. ${ }^{7}$ Face shields were also recommended for staff, especially educators. Students from kindergarten through grade 12 were separated into "packs" to facilitate case tracking. Packs with infected students or staff were evaluated for a distance-learning mode. Daily symptom screening was performed to monitor staff members and students. Those who presented any symptoms were not allowed to enter the school and were evaluated and monitored by an infectious disease physician. An infection control specialist was available for school leaders by phone 5 days a week. We present a descriptive analysis of this cohort. Statistical comparisons were made using the Fisher exact test.

\section{Results}

We received 3,229 answers to daily queries from 315 staff members working onsite during the study period; among them, 55 professionals (17.5\%) reported being symptomatic. The most common initial symptoms were sore throat (56.4\%); fatigue (41.8\%); nausea, vomiting, or diarrhea (38.2\%); headache $(36.4 \%)$; muscle or body aches (34.5\%); cough (30.9\%); fever (21.8\%); shortness of breath (16.4\%); and loss of taste or smell (12.7\%) (Table 1). Among symptomatic professionals, 7 tested positive for SARS-CoV-2 (12.7\%), 38 tested negative (69.1\%), and 10 were not tested $(18.2 \%)$. The presence of fever $(P=.05)$, fatigue $(P<.01)$, and $>5$ symptoms at initial presentation $(P<.01)$ were associated with a SARS-CoV-2positive RT-PCR test.

During the study period, 1 classroom of 6-year-old students had to be closed because of a cluster of 3 students who tested positive. All students from this class remained on distance learning for 14 days, and no other cases were reported thereafter. 
Table 1. The Most Common Initial Symptoms Presented by School Staff

\begin{tabular}{lcccc}
\hline Symptoms & $\begin{array}{c}\text { Total, } \\
\text { No. }(\%)\end{array}$ & $\begin{array}{r}\text { RT-PCR } \\
\text { Positive, } \\
\text { No. (\%) }\end{array}$ & $\begin{array}{r}\text { RT-PCR } \\
\text { Negative } \\
\text { No. (\%) }\end{array}$ & $\begin{array}{c}P \\
\text { Value }\end{array}$ \\
\hline Sore throat & $31(56.4)$ & $3(42.9)$ & $23(60.5)$ & .43 \\
\hline Fatigue & $23(41.8)$ & $7(100.0)$ & $15(39.5)$ & $<.01$ \\
\hline $\begin{array}{l}\text { Nausea, vomiting, } \\
\text { diarrhea }\end{array}$ & $21(38.2)$ & $2(28.6)$ & $14(36.8)$ & 1.0 \\
\hline Headache & $20(36.4)$ & $4(57.1)$ & $14(36.8)$ & .41 \\
\hline Muscle or body aches & $19(34.5)$ & $5(71.4)$ & $12(31.6)$ & .09 \\
\hline Cough & $17(30.9)$ & $4(57.1)$ & $12(31.6)$ & .22 \\
\hline Fever & $12(21.8)$ & $4(57.1)$ & $7(18.4)$ & .05 \\
\hline Shortness of breath & $9(16.4)$ & $2(28.6)$ & $7(18.4)$ & .61 \\
\hline Loss of taste or smell & $7(12.7)$ & $3(42.9)$ & $4(10.5)$ & .06 \\
\hline$\geq 5$ symptoms & $17(30.9)$ & $6(85.7)$ & $11(28.9)$ & $<.01$ \\
\hline Total & $55(100.0)$ & $7(12.7)$ & $38(69.1)$ & \\
\hline
\end{tabular}

Note. RT-PCR, real-time polymerase chain reaction. of transmission among school staff might suggest that the strategies we adopted mitigated the spread of COVID-19 among school staff, even with increasing numbers of infections during November and December 2020. The incidence of cases more than doubled during this period in the state. ${ }^{9}$

Moreover, due to daily screening of minimally symptomatic people, those who worked with symptoms had often done so for $<1$ day. The advice of and tracing by infection disease physicians were crucial, giving the school leaders and staff the support they needed to establish a safe environment.

Pandemic education of school workers, adherence to public health measures, initial symptom screening, and sick-leave policies adopted by schools, as implemented by healthcare institutions, ${ }^{10}$ are essential to blocking transmission events. Although ours was a small study with a short follow-up period, our findings reinforce the low impact of well-organized schools in COVID-19 transmission.

Acknowledgments. We thank Célia Beatriz for administrative support.

Financial support. No financial support was provided relevant to this article.

Conflicts of interest. Qualis received consultation fees from schools. All other authors report no conflicts of interest relevant to this article.

\section{References}

1. Auger KA, Shah SS, Richardson T, et al. Association between statewide school closure and COVID-19 incidence and mortality in the US. JAMA 2020;324:859-870.

2. Massad E, Amaku M, Covas DT, Lopez LF, Coutinho FAB. Estimating the effects of reopening of schools on the course of the epidemic of COVID-19. Epidemiol Infect 2021;149:e86.

3. Li W, Zhang B, Lu J, et al. Characteristics of household transmission of COVID-19. Clin Infect Dis 2020;71:1943-1946.

4. Bunyavanich S, Do A, Vicencio A. Nasal gene expression of angiotensinconverting enzyme 2 in children and adults. JAMA 2020;323:2427-2429.

5. Levinson M, Cevik M, Lipsitch M. Reopening primary schools during the pandemic. N Engl J Med 2020;383:981-985.

6. Ismail SA, Saliba V, Lopez Bernal J, Ramsay ME, Ladhani SN. SARS-CoV-2 infection and transmission in educational settings: a prospective, crosssectional analysis of infection clusters and outbreaks in England. Lancet Infect Dis 2021;21:344-353.

7. Advice on the use of masks for children in the community in the context of COVID-19. World Health Organization website. https://www.who.int/ publications/i/item/WHO-2019-nCoV-IPC_Masks-Children-2020. Updated August 21, 2020. Accessed April 6, 2021.

8. Slifka MK, Gao L. Is presymptomatic spread a major contributor to COVID-19 transmission? Nat Med 2020;26:1531-1533.

9. Painel coronavirus RS. Secretaria de Saúde do Estado do Rio Grande do Sul website. https://ti.saude.rs.gov.br/covid19. Accessed March 24, 2021.

10. Chow EJ, Schwartz NG, Tobolowsky FA, et al. Symptom screening at illness onset of health care personnel with SARS-CoV-2 infection in King County, Washington. JAMA 2020;323:2087-2089. 